DOI: 10.14526/2070-4798-2019-14-4-61-66

\title{
Traumatism prevention of ankle joint among children, who go in for "disco" dancing, at the stage of initial training
}

\author{
Ilona V. Adamova*, Ivana Chirakovich \\ Russian State University of Physical Culture, Sport, Youth and Tourism \\ Moscow, Russia \\ ORCID: oooo-ooo2-5320-3771, Ilona-adamova@rambler.ru* \\ ORCID: oooo-ooo2-1486-6708, Ivana-chirakovich@mail.ru
}

\begin{abstract}
Nowadays "disco" can be considered the type of dancing. Disco is a dance where dancing movements are combined with the elements of gymnastics and a great number of jumps during a quick musical tempo, without acrobatics elements use. In order to master successfully all technique of jumps, it is necessary to training feet for a long-term load. Taking into account age-related characteristics of locomotor apparatus insufficient development and the fact that all children dance without footwear, feet muscles and joints and ankle joint strengthening in order to prevent traumatism is an urgent topic for research. Materials. Experimental and theoretical substantiation of the exercises complex, directed toward angle joint traumatism prevention in 7-8 year-old children during training "Disco" dancing lessons at the initial stage of training. Research methods. Scientific-methodical information and Internet-resources theoretical analysis and summarizing, pedagogical observation, sociological methods (questionnaire survey, plantorgaphy, results interpretation according to V.A. Yarolov-Yaralantsa method), pedagogical experiment, methods of mathematical data handling. Results. The questionnaire survey was held in order to reveal the amount of traumas during the lessons and competitions, their kinds and reasons in the groups of initial training. We created the complex of exercises, directed toward ankle joint traumatism prevention in 7-8 year-old children during the training lessons of "Disco" dancing at the initial stage of training and a complex of exercises for independent everyday work at home. Conclusion. The way of ankle joints traumatism prevention includes specially selected physical exercises. For a successful professional activity feet of a dancer should be flexible, should have sufficient power and power endurance. On the basis of the research results we come to the conclusion that dancing-choreographic exercises can be used as the way of correct bearing formation among children of junior school age.
\end{abstract}

Keywords: junior school age, initial training stage, Disco dancing, ankle joint traumatism prevention.

For citation: Ilona V. Adamova*, Ivana Chirakovich. Traumatism prevention of ankle joint among children, who go in for "disco" dancing, at the stage of initial training. Russian Journal of Physical Education and Sport. 2019; 14(4): 52-56. DOI: 10.14526/2070-4798-2019-14-4-61-66.

\section{INTRODUCTION}

Junior school age is the time when bones and muscles become longer and the mechanisms of pose holding are not adapted to the changes that happened. Deviations are observed in most 7-8 yearold children. Muscles of the extremities (especially small muscles) are relatively weaker, than body muscles. During this period there is intensive foot development. It mainly consists of cartilaginous tissues. Under the influence of mechanical influences a child's foot can easily deform [1].

Easy flexibility of muscle-joint apparatus provides a child's flexibility, but can't create firm "muscle corset" for normal bones position preservation. As a result it is possible to have skeleton, extremities deformation, platypodia. Special attention to children's normal pose and physical loads use is demanded [6].

In studied scientific-methodical literature there are no sufficient works concerning ankle joint traumatism prevention in the system of physical training of children, who go in for "Disco".

New means and methods searching with the main parameters of loads determination are directed toward foot and ankle muscles and joints strengthening, in order to support spring and pushing function of the foot among children, who go in for "Disco" dancing, is the urgency of the research.

The aim of the research: experimental and theoretical substantiation of the complex of 
exercises, directed toward ankle joint traumatism prevention among 7-8 year-old children during the training "Disco" dancing lessons at the initial stage of training.

In order to solve the set objectives we used the following research means: scientificmethodical literature and Internet-resources theoretical analysis and summarizing, pedagogical observation, sociological methods (questionnaire survey,plantorgaphy, results interpretation according to V.A. Yarolov-Yaralants method), pedagogical experiment, methods of mathematical data handling.

\section{RESULTS AND DISCUSSION}

A questionnaire survey was held in order to reveal amount of injuries during the training lessons and competitions, their kinds and their reasons in the groups of the initial training. The questionnaire survey included 8 questions. 17 experts, coaches-teachers, who work with children in different directions of dancing (Disco, Hip-hop, sports ballroom dancing, acrobatic rock-n-roll) in the Centers of additional education in Moscow and Moscow region took part in the questionnaire survey. The average working experience of the experts was no less than 10 years, the average age -31 years-old; all experts had higher education and 50\% had higher special education. From five mentioned above kinds of dancing only in sports ballroom dancing children train and compete wearing special footwear.

Pedagogical observation and pedagogical experiment was held in a Youth Center "Voskhod" in Khimki since September 2017till March 2019.

The main component of the exercises optimization complex, directed toward foot muscles and joints and ankle joints strengthening among children of junior school age, who go in for "Disco", is maximum complete and valid information concerning the training and competitive activity, important physical qualities.

Main attention we paid to hygienic conditions of lessons and the places of competition, the quality and purity of the covering, air temperature.

One of the problems, which most teachers face during their work with children, who go in for different kinds of dancing is often ankle and ankle joint injuries (ankle twisting, joint apparatus sprain). It is conditioned by weakness of the lower extremities muscle-joint apparatus. One of the reasons for this phenomenon is great load on ankle joint. It is connected with the specificity of training lessons and competitive activity. Another reason is the absence of preventive measures, connected with ankle joint strengthening [3,5].

As it is seen from the table, small percentage of small injuries (tensions, bruises and subluxations) happens during the preparatory and competitive periods. The experts made ranking of injuries reasons:

- warming-up wasn't fulfilled properly (without the control of a coach);

- not stable psychological state, connected with the peculiarities of age group;

- worry because of responsibility before the collective and parents;

- no competitive experience;

- low level of technical readiness;

- low level of physical readiness;

At the initial stage of training since the moment of taking beginners till the first official performance there are 5 months, then goes one performance every month. In general 4 competitions a year (February, March, April, May).

On the basis of sociological research results and defined by the experts reasons, which lead to different injuries, the results of plantorgaphy and the accumulated practical and scientific experience (Shorin G.A., Mutovkina T.G., Tarasova T.A. , 1994, Strakovskaya V.L. , 1994, Sharmanova S.B., Fedorov A.I., 1999, Polyaev B.A., Yunusov F.A., Ivanova G.E., Skvoznova T.M., 2007, Khaas Zh.G. , 2011) we created the complexes of exercises for independent everyday work at home and a complex of exercises. It was held directly during "disco" dancing lessons 2 times a week (duration from 10 to 15 minutes depending on the stage of training). At the first stage of the research, which lasted 2 months we created the complex of exercises (8) using the objects and without them. The exercises were fulfilled from the initial position sitting (62,5\%) and standing (37,5\%). During the first lessons all exercises are started with minimal load. At the second stage, which lasted 2 months the number 
of exercises in a complex decreased till 6 and time of their fulfillment increased. The percentage of exercises from the sitting and standing position was equal, it means 50\% (3 exercises) were the exercises from sitting position and 50\% (3 execises) from standing position. 15 minutes were given to fulfill the complex, the same as at the 1 stage. At the third stage (2 months) the created complex included 5 exercises of the increased difficulty and time, dedicated to the complex fulfillment, decreased till 10 minutes. It mainly included the exercises from standing position (on the floor, on the height) and the exercises with rubber ribbon.

Feet provide steadiness, balance, movement, they hold body weight after the jump. Typical foot injury can cause incorrect preparation or the technique of fulfillment. In order to avoid feet injuries and other injuries a dancer and a teacher should follow the rules of correct technique of performance, weight distribution and correct floor covering [4].

A foot changes its form and movements as a result of trainings more often, than any other part of the body. That is why the foot of a young dancer should be adapted to changes, which are necessary during the trainings [7].

In a usual practice of dancing teachers don't pay great attention to disorders concerning locomotor apparatus in the students. It is supposed that the medical permission from the doctor guarantees locomotor health of a child. However, even not thorough study can prove that only some percent of children doesn't have disorders in feet position. In terms of the increased physical and emotional load, general fatigue of an organism, the functions of a foot decrease because of foot arch disorders and it can lead to serious injuries [2].

The means of ankle joints injuries prevention can be specially selected physical exercises [6]. Physical exercises are fulfilled both without weight and with different objects (balls, dumbbells, expander, absorbers, special mats, gymnastic sticks and etc.) from different initial positions (standing, sitting, lying).

During junior school age insufficient muscles development, joints weakness, long-term loads on the foot lead to platypodia. In this case there appears pain in a foot and an ankle, and a person feels tiredness during walking and running [8].

\section{CONCLUSION}

The way of ankle joints traumatism prevention includes specially selected physical exercises.

Nowadays the experience of outstanding Russian scientists in the sphere of dancing (A.A. Sapogov, 2003; Yu.I. Gromov, 2006), specialists in the sphere of physical culture (S.B. Sharmanova, 2001; O.S. Vasilev, 2007), doctors-orthopedists (J.S. Hafiler, 2007) proves that dancingchoreographic exercises have considerable influence on bearing and foot arches formation.

For a successful professional activity feet of a dancer should be flexible, should have sufficient power and power endurance. Foot flexibility means maximum amplitude of movements in ankle joint and foot joints.

On the basis of the research results we come to the conclusion that dancing-choreographic exercises can be used as the way of correct bearing formation among children of junior school age.

\section{REFERENCES}

1. Ilona V. Adamova. Effectiveness of complex lessons with swimming and hatha yoga predominance influence on psychophysical state of 21-35 year-old men. Pedagogiko-psihologicheskie I medico-biologicheskie problemy fizicheskoj kul'tury I sporta $=$ Russian Journal of Physical Education and Sport. 2019; 14(2):43-47. DOI 10.14526/20704798-2019-14-2-43-47 (In Russ., In Engl.).

2. Baeva N.A., Pogadaeva O.V. Anatomiya I fiziologiya letej shkol'nogo vozrasta: uchebnoe posobie [Anatomy and physiology of schoolchildren: manual]. Siberian state University of physical culture and sports, Anatomy and physiology department. - Omsk: SibSUPC publishing House. 2003: 56 (In Russ.).

3. Bogomolova E.S. Ocenka fizicheskoho razvitiya detej I podrostkov: uchebnoe posobie [Children's and teen-agers' physical development assessment: textbook]. N. Novgorod: NSMA Publishing house. 2006: 260 (In Russ.).

4. Goniyants S.A., Adamova I.V., Rvachev V.A. Respiratory technologies in professionalapplied physical culture among electric train drivers in the aspect of adaptation to psycho-emotional loads of professional activity. Pedagogikopsihologicheskie I medico-biologicheskie problemy fizicheskoj kul'tury $I$ sporta = Pedagogico- 
Table - Results of a questionnaire survey among experts ( $\mathrm{n}=17$ )

\begin{tabular}{|c|c|c|c|c|c|}
\hline \multirow[b]{2}{*}{ Questions } & \multicolumn{5}{|c|}{ Dancing direction } \\
\hline & Disco & Hip-hop & $\begin{array}{l}\text { Spots ballroom } \\
\text { dancing }\end{array}$ & Acrobatic rock-n-roll & Capoeira \\
\hline $\begin{array}{l}\text { 1.How } \\
\text { often do } \\
\text { your } \\
\text { students get } \\
\text { injuries? }\end{array}$ & $\begin{array}{c}\text { Once in 6-12 } \\
\text { months }\end{array}$ & $\begin{array}{c}\text { Once in 1-3 } \\
\text { months }\end{array}$ & $\begin{array}{c}\text { Once in6-12 } \\
\text { months }\end{array}$ & Once in $1-3$ months & Once in 2 years and less \\
\hline $\begin{array}{l}\text { 2.Kinds of } \\
\text { injuries }\end{array}$ & \begin{tabular}{|c|} 
tension, \\
meniscus \\
injuries; ankle \\
joints injuries; \\
foot joints \\
apparatus \\
injuries.
\end{tabular} & $\begin{array}{c}\text { Bruises; } \\
\text { tensions; } \\
\text { shoulder joint } \\
\text { injuries; } \\
\text { cruciate } \\
\text { ligaments of } \\
\text { knee injuries; } \\
\text { ankle joints } \\
\text { calves injuries. }\end{array}$ & \begin{tabular}{|c|} 
cruciate \\
ligaments of knee \\
injuries; \\
meniscus \\
injuries; spine \\
injuries.
\end{tabular} & $\begin{array}{l}\text { Tensions and muscles } \\
\text { ruptures; ankle joints, } \\
\text { calves injuries. }\end{array}$ & $\begin{array}{l}\text { Abrasion marks, } \\
\text { concussions, } \\
\text { tensions; } \\
\text { ankle joints, calves } \\
\text { injuries; foot joints } \\
\text { apparatus injuries; } \\
\text { dislocatons and } \\
\text { concussions of foot } \\
\text { fingers, } \\
\text { arm injuries. }\end{array}$ \\
\hline $\begin{array}{l}\text { 3.During } \\
\text { which } \\
\text { period of } \\
\text { activity do } \\
\text { students } \\
\text { have most } \\
\text { injuries? }\end{array}$ & $\begin{array}{l}\text { Preparatory, } \\
\text { competitions }\end{array}$ & Preparatory & Pre-competitive & Competitions & Preparatory \\
\hline $\begin{array}{l}4 . \text { The } \\
\text { reasons for } \\
\text { injuries }\end{array}$ & $\begin{array}{c}\text { 1.Insufficient } \\
\text { wanning-up } \\
\text { before the } \\
\text { main activity. } \\
\text { 2.Low level of } \\
\text { technical and } \\
\text { physical } \\
\text { readiness. } \\
3 . \text { Bad } \\
\text { psychological } \\
\text { state }\end{array}$ & \begin{tabular}{|} 
1.Insufficient \\
warming-up \\
before the main \\
activity. \\
2. Low level of \\
technical and \\
physical \\
readiness. \\
3.Not proper \\
footwear/clothes \\
use. \\
4. Bad \\
psychological \\
state
\end{tabular} & $\begin{array}{l}\text { 1.Insufficient } \\
\text { warming-up } \\
\text { before the main } \\
\text { activity. } \\
\text { 2.Mistakes in } \\
\text { trainings } \\
\text { planning and } \\
\text { training methods. }\end{array}$ & $\begin{array}{l}\text { 1. Insufficient warming- } \\
\text { up before the main } \\
\text { activity. } \\
\text { 2. Low level of } \\
\text { technical and physical } \\
\text { readiness. } \\
\text { 3.Bad psychological } \\
\text { state }\end{array}$ & $\begin{array}{l}\text { 1. Low level of } \\
\text { competitions organization. } \\
\text { 2. Insufficient warming-up } \\
\text { before the main activity. } \\
\text { 3. Bad psychological state. }\end{array}$ \\
\hline 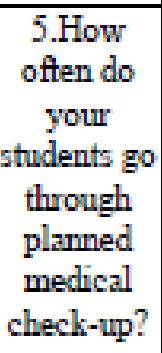 & Once a year & $\begin{array}{l}\text { Once in two } \\
\text { years and less }\end{array}$ & $\begin{array}{l}\text { Once in two } \\
\text { years and less }\end{array}$ & Once in 6 months & Once in 6 months \\
\hline
\end{tabular}


psychological and medico-biological problems of physical culture and sport. 2017; 12 (1): 33-35. DOI 10.14526/01_2017_181 (In Russ., In Engl.).

5. Joseph S. Huwyler. Telo tantsora. Medicinskij vzglyad na tantsy I trenirovki [The body of the dancer. A medical view of dancing and training]. Moscow, Publishing house "New word". 2004: 107 (In Russ.).

6. Kalugina O.G. Metodika prepodavaniya horeograficheskih discipline: uchebnometodicheskoe posobie [Methods of teaching choreographic disciplines: teaching aid]. Kirov: KIPK and PRO. 2010: 123 (In Russ.).

7. McMahon P. Sportivnaya travma: diagnostika I lechenie [Sports injury: diagnosis and treatment]. Moscow: "Practice". 2011:366 (In Russ.).

8. Stupnitskaya M.A. Traumatism among schoolchildren: reason and prevention. Shkola zdorov'ya. 2010: 196 (In Russ.).

9. Haas J.G. Anatomiya tantsa [Anatomy of Dance]. 2011: 204 (In Russ.).

10. Sharmanova S.B., Fedorov A.I. Profilaktika I korrekciya proskostopiya u detej doshkol'nogo I mladshego shol'nogo vozrasta sredstvami fizicheskogo vospitaniya: uchebnoe posobie [Prevention and correction of flat feet among preschool children and primary school children by means of physical education: textbook]. Chelyabinsk: Ural State Academy of Physical Culture. 1999 (In Russ.)

11. Bowers A.L., Baldwin K.D., Sennett B.J. Athletic hand injuries in intercollegiate field hockey players. Medicine and Science in Sports and Exercise. 2008; 40: 2022-2026.

12. Crowley B. A study by telephone interview of adult hurling injuries attending the Emergency Department of Cork University Hospital over a three month period (unpublished manuscript). 2006.

13. Flynn T.H., Fennessy K., Horgan N., Walsh B., O'Connell E., Cleary P., et al. Ocular injury in hurling. British Journal of Sports Medicine. 2005; 39: 493-496.

14. Kiely P.D., Ashraff M., O'Grady P., Dawson M.J., O'Beirne J.G. Hurling-related hand injuries. Injury. 2003; 34: 561-563.

\section{Submitted: 05.11.2019}

\section{Author's information:}

Ilona V. Adamova - Candidate of Pedagogics, Associate Professor, Russian State University of Physical Culture, Sport, Youth and Tourism, 105122, Russia, Moscow, Sirenivy bulvard, House 4, e-mail: Ilonaadamova@rambler.ru

Ivana Chirakovich - Post-graduate, Russian State University of Physical Culture, Sport, Youth and Tourism, 105122, Russia, Moscow, Sirenivy bulvard, House 4, e-mail: Ivana-chirakovich@mail.ru 